\title{
The Triangle of Sensory Marketing Model: Does it Stimulate Brand Experience and Loyalty?
}

\author{
Alex Fahrur Riza', Dwi Marlina Wijayanti² \\ UIN Sunan Kalijaga Yogyakarta \\ 1alex.fahrurriza7@gmail.com,
}

\begin{abstract}
The purpose of this study is to examine the framework of brand experience associating with customer loyalty. Sensory marketing effectiveness is recognized in business contexts but only little research has been conducted on sensory marketing. This study contribute to filling this gap by proposing a model that explains how sensory stimulation influences loyalty. Brand experience is expected to mediate this relationship. This study applies exploratory and explanatory approaches to investigate the sensory marketing concept and examine the framework brand experience in association with customer loyalty. Data is collected using online survey. Respondents are individual who had experience in consuming product at restaurant or cafe that has been using the five senses stimulus. Conceptually, this study found interesting relationship between sensory marketing, brand experience, and customer loyalty then called as triangle sensory marketing. The findings offer an additional insight to managers on sensory marketing strategy to stimulate brand experience that can establish customer loyalty.
\end{abstract}

Keywords: sensory marketing, brand experience, customer's loyalty

\begin{abstract}
Abstrak
Tujuan dari penelitian ini adalah untuk menguji kerangka pengalaman merek yang terkait dengan loyalitas pelanggan. Efektivitas Sensory Marketing diakui dalam konteks bisnis namun hanya sedikit penelitian yang dilakukan pada S. Studi ini berkontribusi untuk mengisi celah ini dengan mengajukan model yang menjelaskan bagaimana stimulasi sensorik mempengaruhi loyalitas. Pengalaman merek diharapkan bisa menengahi hubungan ini. Penelitian ini menggunakan pendekatan eksploratori dan penjelasan untuk menyelidiki konsep pemasaran indrawi dan menguji pengalaman merek kerangka kerja yang terkait dengan loyalitas pelanggan. Data dikumpulkan dengan menggunakan survei online. Responden adalah individu yang memiliki pengalaman dalam mengkonsumsi produk di restoran atau kafe yang telah menggunakan lima indera rangsangan. Secara konseptual, penelitian ini menemukan hubungan yang menarik antara pemasaran sensoris, pengalaman merek, dan loyalitas pelanggan yang kemudian disebut sebagai pemasaran sensoris segitiga. Temuan ini menawarkan wawasan tambahan kepada para manajer mengenai strategi pemasaran indrawi untuk merangsang pengalaman merek yang dapat membangun loyalitas pelanggan.
\end{abstract}

Keywords: sensory marketing, brand experience, loyalitas pelanggan

\section{Cara Mengutip:}

Riza, A. F., \& Wijayanti, D. W. (2018). The Triangle of Sensory Marketing Model: Does it Stimulate Brand Experience and Loyalty?. Esensi: Jurnal Bisnis dan Manajemen. Vol. 8 (1): 57 - 66. doi: 10.15408/ess. v8i1.6058. 


\section{INTRODUCTION}

In a world crowded by the brand, Many companies are competing to get customers' attention. It becomes important to create a brand experience because brand-related stimulus arouse sensations, feelings, cognition and behavioral responses as part of the brand and identity design, packaging, communication and environment (Brakus et al, 2009). The commercial environment has a powerful impact on consumers and is a much-discussed topic among companies (Rodrigues et al, 2011). In the last two decades, marketers in various industries build the expertise to reach consumer through the senses by spreading the cues that reinforce the perception of the brand. In recent years, sensory marketing has become an interesting topic for academics because many company's products and services get benefit through marketing based on the human senses (Krishna and Schwarz, 2014). Currently, the market has undergone significant changes. In past, companies only sell and promote products and services but now they not only do these two things but do sales and find out about the consumer experience for improvement (Brakus et al., 2009; Krishna, 2011). Marketing paradigm also evolved from a focus on transactions and standardized mass production (transactional) into a marketing interaction between the seller and the buyer (relationship), then became a marketing focused on consumer experience based on the five senses (sensory) (Eriksson \& Larsson, 2011; Hultén, 2011).

There are some gaps in sensory marketing research. First, based on meta-analysis performed by (Krishna, 2012). Krishna mentioned that sensory marketing is still needed to learn more. Things that need to be investigated further are related to interaction senses, dominant senses, sensory congruence etc. In the domain of brand experience, few studies that examine the antecedents and the dimensions of the brand experience are suggesting to re-examine the topic because it has not yet been studied extensively by marketing scientists (Brakus et al., 2009; Şahin et al, 2011). According to (Hultén, 2011), the validity of the relationship between sensory marketing and the multi-sensory brand experience should be re-examined. Researchers intends to investigate whether the factors that can make the brand experience affect the purchasing decision process.

Although the sensory marketing and brand experience is believed to have a strong relationship, but what kind of relationship is still a big question for researchers. Several empirical studies have been conducted in the domain of sensory marketing because of the novelty of this concept study raises a lot of gaps to be filled by the academics. The main purpose of this study is to examine the framework of brand experience in association with customer loyalty by using sensory marketing as a stimulus for the creation of customer experiences. In addressing this issue, researcher tries to test empirical research hypotheses to validate the proposed conceptual model. The paper begins with a discussion of the conceptual framework of sensory marketing, brand experience and brand loyalty and is supported by research from neuro marketing.

Sensory marketing is defined by (Krishna, 2012) as marketing that involves the senses of consumers and affect perception, judgment and behavior. The purpose of using the five senses of consumers is to present a feeling satisfied and happy because the focus on sensory experience is based on vision, hearing, smell, touch and taste. Assael (2004) explains that one of the key elements of success in marketing strategy is the development of products and 
promotional stimulus that can build consumer perception. Marketing and environment are two things that are most important in providing stimulus. Elements of sensory stimulus are one of the characteristics of marketing that can affect consumer perception (Krishna, 2011).

Research on human senses show that cues the senses of sight, hearing, smell, touch and feeling may affect preferences, memory, and choice (Krishna, 2011). Jang \& Namkung (2009) state that the structural stimulus and sensorial stimulus from the atmosphere store have positive impact on consumer experience. Some senses have an impact on memory and cognition but olfactory has the most powerful effect on memory (Krishna, 2011). Based on neuromarketing research, individual stimulus will be processed by the brain as a sensation that is processed in the neomammalia brain as cognitive and emotions are processed in the limbic system that will produce the perception of an object or stimulus. Logically, the more positive sensory stimulus provided by the marketer to the consumer, then the consumer perceptions of a brand will be positive.

Most research on brand experience is focused on utilitarian product attributes and categories experience, not the experience provided by the brand. According to Alloza (2008), the brand experience can be defined as the perception of consumers in every moment of contact they have with the brand consist of whether it is in the brand image is projected in advertising, during the first personal contact, and quality's level of the personal treatment they receive.

Brand experience is conceptualized as a sensation, feelings, cognition, and behavioral responses caused by stimulus related brands. Brand is a part of brand design and identity (ie, name, logo), packaging, communication (ie advertising, brochures, websites), and environment (ie stores, events). Stimulus associated brands is a great source of subjective in internal customer responses that called brand experience (Brakus et al., 2009).

The brand experience conceptualization and the development of scale are very important to understand and managing brand loyalty concept (Brakus et al., 2009). Brand experience can be positive or negative and short or long lasting. Furthermore, the brand experience can positively affect consumers satisfaction, brand loyalty, and brand trust (Şahin et al., 2011; Zarantonello and Schmitt, 2010). Empirically, brand experience is different from other brands and concepts that focus on the customer including brand attachment, brand engagement, and delight consumers (Zarantonello \& Schmitt, 2010). Brand experience in this research explain that consumers should be more likely to buy a product again and recommend it to others and less likely to buy an alternative product.

The latest research on brand experience is shifted its focus from defining and measuring the constructs to identify the antecedents and consequences from brand experience (Brakus et al., 2009). Therefore, it is not surprising to see who the most important challenges in the field of brand experience. This study is to empirically prove that brand experience also predict loyalty (Şahin et al., 2011).

Based on the literature review, there are several studies that identify the possible consequences of the brand experience such as (Brakus et al., 2009) and (Zarantonello \& Schmitt, 2010). However, the majority of researchers have not been able to express many potential outcomes related customer brand experience in stimulus models. Elements of 
sensory such as music can be selected to match the buyer profile. The right use of music will have a powerful effect on regular conversions and become a unique, memorable, and fun shopping experience that brings a positive response to buyers in terms of purchasing, satisfaction, and loyalty (Jain \& Bagdare, 2011).

Direct and strong sensory attributes can cause major changes in consumer attitudes. Sensory attributes such as music and lighting can be combined to create atmospherics, highly affect customer evaluations, emotionally passionate, choices, and purchase intentions (Kidwell et al, 2008). In addition, it is possible that the brand experience can play a mediating role in explaining the influence of sensory marketing strategy as stimulus on customer loyalty. Empirically, if the brand experience is able to mediate the relationship between sensory marketing and customer loyalty, it will contribute significantly to marketing management theory.

\section{METHOD}

Data is collected using web-based questionnaire with snowball sampling. Questionnaires is distributed through Google form that share using online social media. Respondents are individuals who have ever consumed food and drink in restaurants or cafes that have used five senses of stimulation. Based on consideration and analysis, culinary industry consumers are selected because the context of brand experience is very suitable for this industry. Sample consisted of 185 randomly selected consumers. All items have good reliability with Cronbach alpha scores above 0.60 . This study uses Structural Equation Modeling (SEM) the measurement model and the structural model.

To test the hypothesis proposed in the model, the questionnaire consists of two parts. The first section is collecting demographic information and the second part is measuring variables in a causal model. Construction in this study is developed using measurement's scale adopted from previous research. All construction is measured using a five-point Likert scale (strongly disagree - strongly agree).

Instrument for sensory marketing (nine items) is built based on the definition of sensory marketing by Krishna (2012). Brand experience (seven items) is adopted from Brakus et al., (2009). This brand results in bodily experiences" and "This brand Stimulates my curiosity and problem solving". Loyalty (seven items) is adopted from Şahin et al., (2011).

\section{RESULT AND DISCUSSION}

To exemine the effect of the variables, each variable operated by confirmatory factor analysis. Means and standard deviations of each variable is calculated by making the correlation matrix of all variables used in hypothesis testing. Means, standard deviations, and correlations between all the scales used in the analysis are shown in Table 1. Means and standard deviations is within the expected range. According to Table 1 the majority of respondents show a relatively higher level of sensory marketing (mean $=3.81)$. This is followed by loyalty (mean $=3.35$ ), the lowest item is brand experience (mean $=3.29$ ). After analyzing the Table 1 , the result show that the relationship between sensory marketing, brand experience, and brand loyalty have positive correlations in the level of $\mathrm{P}<0.01$. 
Table 1. Mean, Standart Deviation and Correlations

\begin{tabular}{cccccc}
\hline Variable & Mean & Std. Deviation & $\begin{array}{c}\text { Sensory } \\
\text { Marketing }\end{array}$ & $\begin{array}{c}\text { Brand } \\
\text { Experience }\end{array}$ & $\begin{array}{c}\text { Costumer } \\
\text { Loyalty }\end{array}$ \\
\hline Sensory Marketing & 3.81 & 0.53 & 1 & & \\
Brand Experience & 3.29 & 0.69 & $0.519^{\star *}$ & 1 & 1 \\
Costomer Loyalty & 3.35 & 0.69 & $0.543^{\star *}$ & $0.472^{\star *}$ & 1 \\
\hline
\end{tabular}

${ }^{*}$ Correlation is significant at level $p<0.05,{ }^{* *} p<0.01$ (one tailed)

Harman's single factor testing is conducted to investigate whether common method variance biases the data in this study and all items are put in the exploratory factor analysis. By using principal component analysis method, the number of factors that must be taken is limited to 1 without any rotation. The percentage of variance for the sum of squares loading is $32.4 \%$. Additionally, no general factor is found in unrotated factor structure. So, there is no problem about CMV in this study.

Table 2. Model Loadings and Cronbach's Alpha

\begin{tabular}{|c|c|c|}
\hline Variables & Loadings & Cronbach's Alpha \\
\hline \multirow[t]{9}{*}{ Sensory Marketing } & 0.540 & 0.861 \\
\hline & 0.600 & \\
\hline & 0.409 & \\
\hline & 0.630 & \\
\hline & 0.414 & \\
\hline & 0.565 & \\
\hline & 0.814 & \\
\hline & 0.766 & \\
\hline & 0.787 & \\
\hline \multirow[t]{7}{*}{ Brand Experience } & 0.772 & 0.838 \\
\hline & 0.842 & \\
\hline & 0.715 & \\
\hline & 0.579 & \\
\hline & 0.425 & \\
\hline & 0.551 & \\
\hline & 0.504 & \\
\hline \multirow[t]{7}{*}{ Customer Loyalty } & 0.583 & 0.863 \\
\hline & 0.828 & \\
\hline & 0.723 & \\
\hline & 0.674 & \\
\hline & 0.655 & \\
\hline & 0.672 & \\
\hline & 0,730 & \\
\hline
\end{tabular}

An Explanatory Factor Analysis is needed to build the items of instrument sensory marketing and then retested with Confirmatory Factor Analysis. The result show that 9 
items can be used to measure the sensory marketing. Then reserchers did the CFA to test brand experience and customer loyalty. Each variable get 7 items. 1 item of brand experience and 1 item of customer loyalty deleted from the model because they have low score. This factor analizes using principal component analysis with VARIMAX rotation. Table 2 shows thesummarize of the results in this research. Based on Table 2, KMO-Barlets score is 0,852 with a significance level 0.000 , according to the score obtained in the Kaiser-Meyer-Olkin measurement, the result of the analysis can be considered excellent.

To examine the hypotheses, a structural model is computed using AMOS21. Refers to research conducted by (Kidwell et al., 2008) the recommended value of The Goodness of Fit Index (GFI) is $>0.80$, Root Mean Square Residual (RMSEA) is $<0.08$, Comparative Fit Index is $>0.90$, and CMIN is $<2$. Results of this study show that GFI is 0.835 , CFI is 0.894 , RMSEA is 0.071 , and CMIN is 1.844 . From several scores of model fit, we can see that model fits the data well. All path coefficients in the model are significant $(\mathrm{p}<0.01)$.

As researchers predicted, sensory marketing affects brand experience and customer loyalty directly and indirectly. The total direct effect and indirect effects of sensory marketing on customer loyalty are roughly equal. The total direct effect on customer loyalty is 0.75 . $(0.369+0.381)$, the total indirect effect is 0 (Brakus et al., 2009,155 $(0,407 \times 0.381)$, and total effect of sensory marketing on customer loyalty is 0.905 . This result relate to the nature of the experience. When a brand stimulates the senses, then the individual will feel good. Furthermore, the mind and body will try to receive the stimulus again and will form customer loyalty (Brakus et al., 2009).

The path estimates from sensory marketing to brand experience in Figure 1 supports for hypotheses 1 . It means that sensory marketing as stimulus has positive effect on consumers' brand experience. This result support the research from Hultén, Broweus, \& Dijk (2009), Rodrigues et al., (2011), Moreira, Fortes, \& Santiago, (2017) which states that the sensory marketing strategy has positive effect on brand experience. A hypothesis 2 is also supported and can be seen in the path estimates from brand experience to customer loyalty. The results of this study support the research conducted by (Brakus et al., 2009) and (Şahin et al., 2011) which states that the brand experience has positive effect on loyalty.

Table 4. The Result of Hypothesis Testing

\begin{tabular}{lccc}
\hline \multicolumn{1}{c}{ Hypotheses } & Standardized Estimates & C.R. & Conclusion \\
\hline H1: sensory marketing $=>$ brand experience & $0.407^{\star \star \star}$ & 4.030 & Supported \\
H2: brand experience $=>$ customer loyalty & $0.381^{\star \star *}$ & 3.962 & Supported \\
H3: sensory marketing $=>$ customer loyalty & $0.369^{\star \star *}$ & 3.582 & Supported \\
H4: sensory marketing $=>$ brand experience & $0,155^{\star \star *}$ & - & Supported \\
$=>$ customer loyalty & & & \\
${ }^{* * *} p<0.01,{ }^{* *} p<0.05$, & & &
\end{tabular}

Furthermore, hypotheses 3 and 4 hypotheses is supported. It is becoming interesting findings for marketing scholars. Sensory marketing can build customer loyalty directly. Brand experience is also partly mediated sensory marketing for customer loyalty. These 
results contribute to the company to design a sensory marketing strategy because it can stimulate a positive brand experience for customers and be able to influence customer loyalty. Researchers hope that the discovery of this study is enough to give an explanation of the antecedents of the brand experience.

The path estimates from sensory marketing to brand experience in Figure 1 support for hypotheses 1. It means that sensory marketing as stimulus has positive effect on consumers' brand experience. This result support the research from Hultén et al (2009); Rodrigues et al., (2011); Moreira et al (2017) which states that the sensory marketing strategy has positive effect on brand experience. A hypothesis 2 is also supported and can be seen in the path estimates from brand experience to customer loyalty. The results of this study support the research conducted by (Brakus et al., 2009) and (Şahin et al., 2011) that states that the brand experience has positive effect on loyalty.

Figure 1. The Result of Full Model

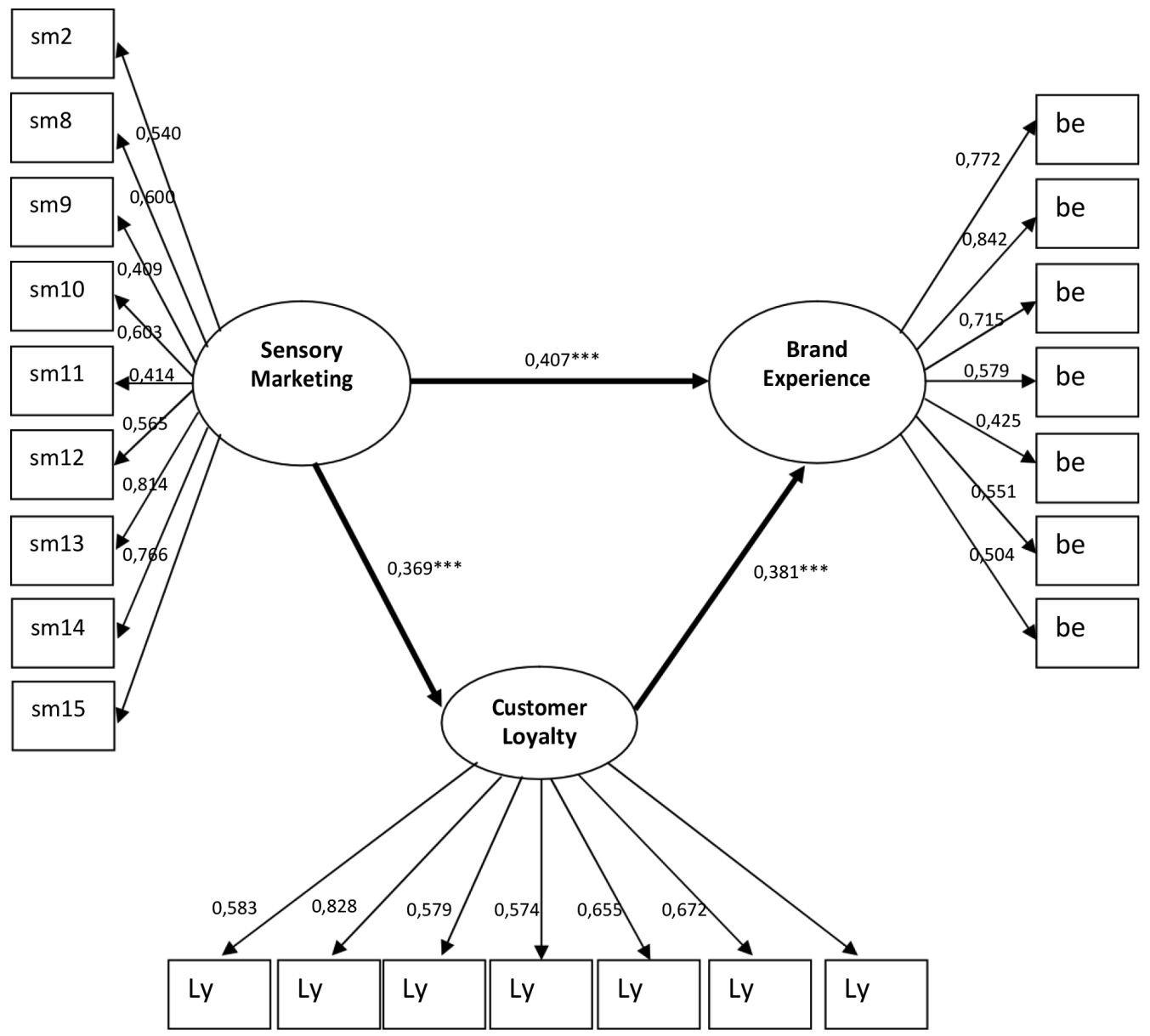

Furthermore, hypotheses 3 and 4 hypotheses is supported. It is becoming interesting findings for marketing scholars. Sensory marketing can build customer loyalty directly. Brand experience is also partly mediated sensory marketing for customer loyalty. These results contribute to the company to design a sensory marketing strategy because it can 
stimulate a positive brand experience for customers and be able to influence customer loyalty. Researchers hope that the discovery of this study is enough to give an explanation of the antecedents of the brand experience.

Today, the market is experiencing significant changes in sales, product promotions, and services that appeal to consumers(Brakus et al., 2009; Hultén et al., 2009). This experience often includes a physical environment consists of environmental cues lighting, color, and music. These factors have a major impact on consumer behavior(Grönroos, 2008). Krishna (2011) explains the information by the sense that the data collected from the environment and compared with previous experiences for the sake categorization. By understanding the logic of experience, the company can use the strategy of sensory marketing as an approach to communicate to their customers using five senses.

Research finding by (Hultén, 2011) supports the idea that multi-sensory brand experience build a personal touch that involves five senses in a customer mind. Regarding sensory attributes, Kim and Perdue (2013) (Hultén et al., 2009) shows that managers can effectively differentiate their properties by including affective and sensory attributes in their promotions to influence consumer behavior in choosing a hotel. It means that tourism industry also requires five senses dimensions that can represent the brand experience (Ghosh and Sarkar, 2016; Seonjeong et al, 2018).

Many human senses have not been noticed in the field of marketing. Over the last decade, they have been receiving more and more attention and emphasizes their meaning to consumers experience and behavior (Rodrigues et al., 2011). Human senses goals in marketing is to give consumers excitement, satisfaction, and pleasure. Each of the five senses is the basis of what is called a sensory experience (Hultén et al., 2009). A sensory experience is the result of sensory reactions to different elements or trigger in marketing (Hultén, 2011). To identify the dimensions of sensory marketing, researchers assess research concerned about the human sense as a stimulus. In this literature and in various disciplines, the variable that is quite consistent about the five senses associated with the dimensions of experience is very relevant to the brand.

The dimensions of sensory brand experience focus on consumer senses of sight, sound, smell, taste, and touch. Brakus et al. (2009) propose four dimensions of brand experience consist of sensory, affective, behavioral and intellectual. This is the fourth construct upon which consumers have experience with the brands they consumed. Affective dimension refers to consumer emotions and inner feelings towards the brand. Cognitive dimension involves creative thinking customers and how to reproduce the things in different ways. Behavioral dimension refers to the physical experience of customer's life. Finally, the social dimension refers to the experience in the pursuit of moving outside individualism-collectivism by involving people, groups, or communities (Brakus et al., 2009; Zarantonello and Schmitt, 2010). Based on the factor analysis testing used in this study, it can be concluded that the sensory marketing is different from the concept of sensory proposed by (Brakus et al., 2009).

Suggested by the researchers, sensory marketing strategy is used as an approach to communicate to their customers through sensory stimulus. So, it can reduce information overload and create a positive customer experience of the brand. Reserchers hope that using application of sensory marketing strategy make customers satisfied and loyal to the brand 
because the brand is already embedded in the customer's memory as the wonderful brand. Certainly, it will be difficult for consumers to switch to another brand.

\section{CONCLUSION}

This study found that sensory marketing can positively influence in establishing consumers' experience on brands and has a positive effect on customer loyalty. Supported previous research, this study clearly express a positive brand experience that will affect customer loyalty. Conceptually, this study found a pretty interesting relationship between sensory marketing, brand experience, and customer loyalty then refers to triangle sensory marketing. This study is contribute to knowledge in marketing field and consumer behavior and then can be references for future research. Limitations in research surely is always existed. Therefore, the research still requires advanced study to reinforce the concept from sensory marketing especially in the establishment of customer lifetime value (Brakus et al., 2009; Şahin et al., 2011).

The present study shows that the human senses sensory cues sight, sound, smell, taste, and touch all can affect our preferences, memories, and choices (Krishna, 2011). It can be used by companies as a strategy to stimulate customers to feel comfortable, satisfied, value to an individual, brand image and loyal (Hultén et al., 2009; Krishna, 2012; Rodrigues et al., 2011). A limitation in research surely is always existed. Some ways, this could probably be a suggestion for future researchers as the impact of sensory marketing. Furthermore, it can further validate these findings by compiling and using other approaches to examine the concept of triangle sensory marketing. The results are expected to be a reference for managers as consideration for the use of sensory marketing in their business activities, so the perception of consumers regarding the positive brand image will be embedded in their memory for the long term. This will cause consumers become loyal to the brand and become a customer lifetime.

\section{REFERENCES}

Alloza, A. (2008). Brand Engagement and Brand Experience at BBVA, the Transformation of a 150 Years Old Company. Corporate Reputation Review. Vol. 11(4): 371-379. doi: https:// doi.org/10.1057/crr.2008.31

Assael, H. (2004). Consumer Behavior: A Strategic Approach. New York: Houghton Mifflin

Kidwell, B., Hardesty, D. M., \& Childers, T. L. (2008). Consumer Emotional Intelligence: Conceptualization, Measurement, and the Prediction of Consumer Decision Making. Journal of Consumer Research. Vol. 35(1): 154-166. doi: https://doi.org/10.1086/524417.

Brakus, J. J., Schmitt, B. H., \& Zarantonello, L. (2009). Brand Experience: What Is It? How Is It Measured? Does It Affect Loyalty? Journal of Marketing. Vol. 73(3): 52-68. doi: https://doi. org/10.1509/jmkg.73.3.52

Eriksson, E., \& Larsson, N. (2011). A Multi-Sensory Brand-Experience: Sensorial Interplay and Its Impact on Consumers' Touch Behaviour. (Unpubished Thesis). Växjö, Sweden: Linnaeus School of Business and Economics. Retrieved from http://lnu.diva-portal. org/smash/record.jsf?pid=diva2:420903 
Ghosh, T., \& Sarkar, A. (2016). To Feel a Place of Heaven: Examining The Role of Sensory Reference Cues and Capacity for Imagination in Destination Marketing. Journal of Travel and Tourism Marketing. Vol. 33: S25-S37. doi: https://doi.org/10.1080/10548408.2014.997962

Grönroos, C. (2008). Service Logic Revisited: Who creates Value? and Who Co-creates? European Business Review. Vol. 20(4):298-314.doi: https://doi.org/10.1108/09555340810886585

Hultén, B. (2011). Sensory Marketing: The Multi-sensory Brand Experience Concept. European Business Review. Vol. 23(3): 256-273. doi:https://doi.org/10.1108/09555341111130245

Hultén, B., Broweus, N., \& van Dijk, M. (2009). Sensory Marketing. New York: Palgrave Macmillan. doi: https://doi.org/10.1057/9780230237049

Jain, R., \& Bagdare, S. (2011). Music and Consumption Experience: A Review. Music and Consumption Experience: A Review. Vol. 39(4): 289-302. doi: https://doi. org/10.1108/09590551111117554

Jang, S., \& Namkung, Y. (2009). Perceived Quality, Emotions, and Behavioral Intentions: Application of an Extended Mehrabian-Russel Model to Restaurants. Journal of Business Research. Vol. 62(4): 451-460.

Kim, D., \& Perdue, R. R. (2013). The Effects of Cognitive, Affective, and Sensory Attributes on Hotel Choice. International Journal of Hospitality Management. Vol. 35: 246-257. doi: https://doi.org/10.1016/j.ijhm.2013.05.012

Krishna, A (eds). (2011). Sensory marketing: Research on the sensuality of products. New York: Routledge. doi: https://doi.org/10.4324/9780203892060

Krishna, A. (2012). An Integrative Review of Sensory Marketing: Engaging the Senses to Affect Perception, Judgment and Behavior. Journal of Consumer Psychology. Vol. 22 (3): 332-351. doi: https://doi.org/10.1016/j.jcps.2011.08.003

Krishna, A., \& Schwarz, N. (2014). Sensory Marketing, Embodiment, and Grounded Cognition: A Review and Introduction. Journal of Consumer Psychology. Vol. 24(2): 159-168. doi: https://doi.org/10.1016/j.jcps.2013.12.006

Moreira, A. C., Fortes, N., \& Santiago, R. (2017). Influence of Sensory Stimuli on Brand Experience, Brand Equity and Purchase Intention. Journal of Business Economics and Management. Vol. 18(1): 68-83. doi: https://doi.org/10.3846/16111699.2016.1252793

Rodrigues, C., Hulten, B., \& Brito, C. (2011). Sensorial Brand Strategies for Value Co-Creation. Journal of Innovative Marketing. Vol. 7(2): 40-47. Retrieved from https://repositorioaberto.up.pt/bitstream/10216/71090/2/51377.pdf

Şahin, A., Zehir, C., \& Kitapçi, H. (2011). The Effects of Brand Experiences, Trust and Satisfaction on Building Brand Loyalty; an Empirical Research on Global Brands. Procedia Social and Behavioral Sciences. Vol. 24: 1288-1301. doi: https://doi.org/10.1016/j. sbspro.2011.09.143

Seonjeong, L., Miyoung, J., \& Oh, H. (2018). Enhancing Customers's Positive Response: Applying Sensory Marketing to The Hotel Website. Journal of Global Scholars of Marketing Science. Vol. 28(1): 68-85. doi: https://doi.org/10.1080/21639159.2017.1410772

Zarantonello, L., \& Schmitt, B. H. (2010). Using The Brand Experience Scale to Profile Consumers and Predict Consumer Behaviour. Journal of Brand Management. Vol. 17(7): 532-540. doi: https://doi.org/10.1057/bm.2010.4. 